\title{
Consequences of the size structure of fish populations for their effects on a generalist avian predator
}

\author{
Janusz Kloskowski
}

Received: 26 September 2009/Accepted: 18 November 2010/Published online: 12 December 2010

(C) The Author(s) 2010. This article is published with open access at Springerlink.com

\begin{abstract}
Size-structured interspecific interactions can shift between predation and competition, depending on ontogenetic changes in size relationships. I examined the effects of common carp (Cyprinus carpio), an omnivorous fish, on the reproductive success of the red-necked grebe (Podiceps grisegena), an avian gape-limited predator, along a fish size gradient created by stocking distinct agecohorts in seminatural ponds. Young-of-the-year $(0+)$ carp were an essential food source for young grebes. Only adult birds were able to consume 1-year-old $(1+)$ fish, while 2-year-old $(2+)$ fish attained a size refuge from grebes. Amphibian larvae were the principal alternative prey to fish, followed by macroinvertebrates, but the abundance of both dramatically decreased along the carp size gradient. Fledging success was 2.8 times greater in ponds with $0+$ versus $1+$ carp; in ponds with $1+$ carp, chicks received on average 2.6-3 times less prey biomass from their parents, and over $1 / 3$ of broods suffered total failure. Breeding birds avoided settling on $2+$ ponds. These results show that changes in prey fish size structure can account for shifts from positive trophic effects on the avian predator to a negative impact on the predator's alternative resources. However, competition did not fully explain the decrease in
\end{abstract}

Communicated by Craig Osenberg.

Electronic supplementary material The online version of this article (doi:10.1007/s00442-010-1862-3) contains supplementary material, which is available to authorized users.

J. Kloskowski ( $₫)$

Department of Nature Conservation, Institute of Biology,

M. Curie-Skłodowska University, Akademicka 19,

20-033 Lublin, Poland

e-mail: januszkl@poczta.umcs.lublin.pl grebe food resources in the presence of large fish, as carp and grebes overlapped little in diet. In experimental cages, $1+$ carp totally eliminated young larvae of amphibians palatable to fish. In field conditions, breeding adults of palatable taxa avoided ponds with $1+$ and older carp. Nontrophic interactions such as habitat selection by amphibians or macroinvertebrates to avoid large fish may provide an indirect mechanism strengthening the adverse bottom-up effects of fish on birds.

Keywords Common carp - Competition . Pond community · Predator-prey dynamics . Trait-mediated effects

\section{Introduction}

Interactions between predators and prey are highly dynamic and depend on the relative body size of the interacting species. The effects of prey on predators can be particularly diverse in stage- and size-structured systems, where the ontogenetic stages of predators may be affected differently by the distinct life stages or cohort-specific body size of prey (e.g. Werner and Hall 1979; De Roos and Persson 2002; Urban 2007). Previous research on sizestructured interactions has focused on reciprocal influences shifting between predation and competition in closed systems (mainly in invertebrates and fish), where the dynamics of predator and prey populations have been strongly interdependent, whereas migration has been demographically negligible (Werner and Gilliam 1984; Neill 1975; Byström et al. 1998). It has been shown that, if young predators and their future prey share resources, the prey can limit the recruitment of their predator (Werner and Hall 1979; Neill 1975; Olson et al. 1995). We know much less 
about bottom-up influences in size-structured systems, which are open, i.e., at least for a part of the community migration between habitats is allowed and population dynamics depend on dispersal and settlement rates (Cooper et al. 1990). In open systems, effects associated with habitat selection, such as avoidance of predators or strong competitors, can play an important role in structuring the community (Lima and Dill 1990; Abrams 1992). Analogous to predator-prey influences mediated by consumption of a third species ("density-mediated indirect effects"), two-species interactions can be changed by such antipredator responses in other species ("trait-mediated indirect effects"; sensu Abrams et al. 1996; Werner and Peacor 2003)

I investigated size-dependent interactions between the common carp (Cyprinus carpio), an omnivorous fish, and the red-necked grebe (Podiceps grisegena) (hereafter: grebe), a medium-sized generalist avian predator, to determine mechanisms behind the effects of progressively larger prey fish on the bird's reproductive success. As amphibian larvae were the grebes' primary alternative food resource in the study system, I examined the impact of carp on pond-breeding amphibians on the assumption that carpamphibian interactions may indirectly affect grebes. Many temperate amphibians prefer breeding sites that lack fish or have low fish abundance (e.g. Resetarits and Wilbur 1991; Hopey and Petranka 1994; Binckley and Resetarits 2002), thus I investigated whether the effects of carp on abundance of amphibian larvae were mediated by habitat selection of adult amphibians in response to the size structure of carp populations. I predicted that small-sized carp would enhance the reproductive success of grebes as an appropriate food source and have limited ability to affect alternative prey, (i.e. amphibians and macroinvertebrates), whereas attainment of relatively large body size should increase the carp's potential to compete with birds for food. At many breeding and wintering sites, grebes prey largely on fish, but they are also adapted to feed on a wide variety of non-fish prey (Madsen 1957; Fjeldså 1982; Piersma 1988; reviewed in Vlug 2002) and are even reported to avoid sites with dense fish populations to reduce competition for invertebrate prey (Wagner and Hansson 1998). Grebes are gape-limited predators and carp is one of several species of cyprinids able to reach a size refuge from piscivorous birds (Crivelli 1981; Moser 1986). Carp and grebes have fundamentally different foraging modes. Although grebes may pick invertebrates from vegetation and the water's surface, they typically pursue prey while diving in open water (Fjeldså 2004). Carp most frequently feed by collecting bottom sediment and sifting out food, but will also forage in the water column (Sibbing 1988).

Although the effects of fish on birds have received much attention (e.g. Eriksson 1979; van Eerden et al. 1993;
Paszkowski and Tonn 2000), no research to date has explicitly addressed effects of fish on birds in size-structured systems. Even though birds lack complex life cycles and intraspecific variation in size during ontogeny is relatively small (Werner and Gilliam 1984), young and adult stages may differ in resource use owing to gape-limitation. The scarcity of studies on size-dependent effects of prey on predators in bird-fish systems can be attributed to the difficulty in conducting research at spatial scales large enough to yield results relevant at the natural community level. Thus, whole-system "experiments in nature" may be the only alternative, even at a potential cost of limitations in experimental design (Diamond 1986; Byström et al. 1998). Extensive pond fisheries provide an attractive model system for research on fish-bird interactions (Ulenaers et al. 1992; Haas et al. 2007), amenable to standardised manipulations and large-scale replication. In the present study, I examined the effects of carp on its avian predator along a gradient of fish size in a semi-natural system of ponds, where cohorts of carp differing in age, and thus body size, were separately stocked. I compared grebe reproductive success, their parental feeding performance and the availability of alternative food resources in ponds differing with regard to carp presence/absence and carp size structure. To explore the character of the grebe-carp interactions, I surveyed the diets of grebes and of different year-classes of carp. As abundance of the non-fish prey of grebes decreased along the carp age/size gradient in ponds, field experiments were conducted to provide insight into the mechanisms of size-dependent impacts of carp on amphibian larvae. Also, I compared patterns of habitat selection by breeding amphibians among ponds containing carp stocks that differed in age and size-structure.

\section{Materials and methods}

\section{Study system}

Data on grebe breeding success and parental feeding were gathered between 1993 and 2007 at 61 extensively managed carp ponds (five pond-complexes), SE Poland $\left(51^{\circ} 08^{\prime}-27^{\prime} \mathrm{N}, 22^{\circ} 16^{\prime}-53^{\prime} \mathrm{E}\right)$. These man-made, drainable ponds were similar in morphometry (range of mean depths: $0.8-1.3 \mathrm{~m}$ ), but differed in size (range 0.9-12 ha and one pond of $23 \mathrm{ha}$ ) and coverage of emergent aquatic vegetation. Field research was conducted in cooperation with the local fisheries staff, who provided data on fish stocks. Size/ age structure was created by stocking three carp age classes separately: young-of-the-year $(0+)$ stocked as larvae shortly after hatching; fish that had overwintered once $(1+)$ and 2-year old fish $(2+)$. Additionally, each year, 1-7 ponds were left unstocked during the posthatching period 
of grebes (hereafter, carp-free ponds). Data on carp stocks in 2001, 2002 and 2004, when the ponds were sampled for abundance of non-fish prey of grebes, are summarised in the electronic supplementary material (Table S1). Due to substantial differences in fish size between year-classes (Table S1), I hereafter consider carp age and age-specific size range to be interchangeable.

The age of stocked fish was changed in $30-60 \%$ of the ponds (including unstocked ponds) each year. Thus, carp age/size effects were separated from environmental properties of the individual ponds in a quasi-cross-over design. Carp densities at stocking were within ranges encountered in the wild (Crivelli 1981) and total fish densities in shallow productive lakes (Scheffer 1998). Supplementary food (cereal grains in the amount of 3-10\% of the estimated fish biomass daily) was supplied to $0+$ fish beginning in July and to $\geq 1+$ cohorts beginning in May.

In central Europe, fish ponds provide the primary nesting habitat for grebes (Vlug 2002) as they mimic their natural breeding sites. Grebes prefer shallow waterbodies often with a maximum depth of $1.5 \mathrm{~m}$ (Vlug 2002). Their natural habitats are frequently perturbed between consecutive reproductive seasons. Temperate shallow lakes and ponds are particularly prone to catastrophic disturbances, especially winter hypoxia and drought, promoting strong size structure of fish communities or even domination by single species' cohorts (Scheffer 1998; Richardson et al. 1995; Paszkowski and Tonn 2000). Breeding birds arrived at the studied ponds during April when they were free of ice. Egg laying typically occurred from early May through June.

Differential susceptibility of carp year classes to grebe predation

Grebes are gape-limited predators as they swallow prey whole. The average bill length (measured from the distal tip of bill to the corner of the mouth) in adult birds from the study population differed slightly between sexes: $53.8 \pm$ SE $0.4 \mathrm{~mm}$ in males versus $49.9 \pm 0.5 \mathrm{~mm}$ in females (mean body weights $820 \mathrm{~g}$ and $739 \mathrm{~g}$, respectively; Kloskowski et al. 2006). Adult grebes were observed in the field to ingest prey up to 2.5 times their bill length (Kloskowski 2004). Thus, the upper size limit for prey fish would be 120-140 mm total length (TL). This range conforms to the maximum size of fish found in the guts of adult grebes in Europe (Madsen 1957; Piersma 1988). Young grebes have smaller bills that restrict their prey range. At hatching, bill length averaged only $11.0 \pm \mathrm{SE} 0.3 \mathrm{~mm}$ (average body weight $=19.5 \mathrm{~g} ; n=22$ ). Parents usually feed young for 6-8 weeks until they nearly attain adult size (Vlug 2002). Given the average body sizes of different-aged carp (Table $\mathrm{S} 1$ ), during the prefledging period (late May-July), $0+$ fish were expected to be available in large supply for both young and adult birds, average-sized $1+$ carp to be near the upper size-limit that adult birds can handle, but too large to be potential prey for chicks in their first weeks of life, and $2+$ fish to be completely free from grebe predation. Grebes are unable to walk; until the young fledge, broods are confined to the nesting pond. However, breeding grebes may perform foraging flights to other waterbodies (Ohanjanian 1989).

\section{Estimation of grebe reproductive success}

Each study pond was visited at 1- to 7-day intervals between mid-April and the beginning of August to locate breeding pairs and nests, and to determine clutch size, hatching date and number of chicks surviving. Nests detected after the start of hatching and clutches with assumed partial losses (<3 eggs) were excluded from calculation of clutch size $(n=231)$. Also, it was sometimes not possible to distinguish between early post-hatching mortality and abandonment of the youngest, unhatched eggs, which were usually quickly depredated (Kloskowski 2003). Since 1996, breeding grebes have been captured with submerged nets and by 'nightlighting', sexed using PCR-based sex-specific genetic markers, and given a unique combination of metal and colour rings (Kloskowski et al. 2006). To facilitate observations, ringed birds were colour-marked with dye on the head.

The number of young raised to independence was used as a measure of reproductive success to evaluate factors affecting grebe breeding performance. As ringed birds were involved in only $37 \%(n=102)$ of the recorded breeding attempts with successful hatching (at least one chick hatched), an element of pseudoreplication was introduced to the analyses in that all observed breeding pairs $(n=275$; $14-28$ broods each year; $2+$ ponds excluded) were interpreted as independent observations. The mean fledging success per pond (some ponds were inhabited by more than one pair) in the given year ( $n=202$ datum points) was used in the analyses.

\section{Grebe diet and parental feeding performance}

Data on parental feeding were collected from breeding grebe pairs that hatched $1-4$ chicks ( 23 pairs on $0+$ ponds, 20 on $1+$ ponds, and 7 on carp-free ponds). In all focal pairs except two on carp-free ponds, at least one adult was ringed and marked pairs were included only once in analyses. Observations from the first four post-hatching weeks were used, as this initial period determines chick survival to fledging (Kloskowski 2001). In the first weeks of life, the young are totally dependent on parental provisioning; as a result, all prey items ingested by chicks 
could be recorded during food transfers. Continuous 2- to 8-h observations of focal grebe families were performed at 2- to 5-day intervals. Prey lengths were estimated visually in relation to the adult's bill length (Ulenaers et al. 1992; Jackson 2003). Bill length was measured in all ringed adults. For birds that were not captured, the mean male or female bill length was applied for prey size estimates. For prey transfers where the provisioning parent remained unidentified, the mean bill length calculated for both sexes was used. Assessment of prey size was practised and showed high levels of accuracy when its reliability was tested with a model grebe (Kloskowski 2001). Prey items were identified by body form and coloration to the lowest taxon possible. Prey $>20 \mathrm{~mm}$ body length were usually distinguishable to order. The most serious problem was the taxonomic identification of small invertebrates. Prey length estimates were converted to approximate fresh mass of food transported using predictive equations based on measurements from individuals collected within the study area (detailed methods in Kloskowski 2004). Contribution of prey categories to the diet of young grebes was quantified based on a prey category's biomass relative to the estimated total biomass of ingested prey.

\section{Grebe and carp gut content analyses}

To expand information on the taxonomy and developmental stage of invertebrates taken by grebes, and to compare grebe and carp diets, alimentary tracts of grebes collected fresh (within ca. $24 \mathrm{~h}$ ) after sudden death (killed due to collision with power lines during flights between the ponds, killed by predators or drowned in nets) in late April-June between 1994 and 2006 were analysed. To avoid biases resulting from potential competition with large-sized carp (see "Results"), all specimens were either from $0+$ or carp-free ponds or were collected soon after $1+$ carp stocking. Carp from each year-class were collected in June-July 2002 and 2004. Carp diet analyses focused on animal prey as vegetable food was dominated by supplemented feed cereals. Carp and grebe alimentary tracts were dissected immediately after collection and their contents individually frozen or preserved in $4 \%$ formalin. Key body parts were used to analyse prey remains from the alimentary tracts and to estimate the minimum number of prey individuals. Prey were identified to order or lower. Weight of food components as an expression of dietary importance was impractical, as the size of body parts and consequently total prey size could rarely be precisely determined. Therefore, the contribution of food categories in the diets was expressed as percentages of numbers of individuals in each food category relative to the total number of prey individuals, although this method underestimates the role of macroinvertebrate taxa relative to the microcrustaceans in carp diets. However, diet comparisons focused on macroinvertebrate prey (see below).

The degree of diet overlap between grebes and carp of different ages was calculated using the Schoener percent similarity index (SI; Schoener 1970). Adult birds and chicks were pooled because gut analyses focused on invertebrate prey and chicks were not notably gape-limited relative to adults when consuming invertebrates. Only prey items used by both carp and grebes were considered. SI ranges from 0 , when no food is shared, to 1 , indicating complete overlap between species. SI values $>0.6$ are considered to be a biologically significant degree of diet overlap (Wallace 1981).

\section{Sampling of availability of non-fish prey for grebes}

Densities of amphibian larvae and aquatic invertebrates were estimated from pond surveys using activity traps in 2001, 2002 and 2004 (50-54 ponds were sampled each year). In 2003, only ponds with grebe families were sampled $(n=15)$. Sampling periods were adjusted to grebe breeding phenology; the traps were set in the third or fourth week after the median brood hatching date. In 2001, traps were set from 8 to 23 July and in 2002-2004 from 19 June to 4 July. The traps (constructed after Murkin et al. 1983; Griffiths 1985) were plastic bottles with a 23-mm aperture at the narrow end of the funnel. Ten traps, set for $48 \mathrm{~h}$, were deployed approximately evenly along the shoreline of each pond at the interface between emergent vegetation and open water. In shallow ponds with dense submerged vegetation, trapping appears to be superior to dip-nets for sampling larger, free-swimming macrozoa (Murkin et al. 1983; Kloskowski 2009). Invertebrates $\geq 4 \mathrm{~mm}$ (hereafter macroinvertebrates) caught in traps were identified typically to family or genus; amphibians were pooled in a single category. Amphibians were weighed in the field after drip-drying and released. For common macroinvertebrate taxa, dry weights were calculated from length to weight regressions obtained after drying subsamples to stable weight at $50-60^{\circ} \mathrm{C}$. Macroinvertebrates from rare taxa were collected and weighed after drying. As bioturbation induced by feeding by benthivorous fish, including carp, may potentially affect prey availability for waterbirds (Scheffer 1998), water transparency (Secchi depth) was measured on each sampling occasion.

\section{Predator enclosure/exclosure experiment}

To elucidate the mechanisms by which carp affect amphibian larvae, the main alternative prey of grebes (see "Results"), a predator enclosure/exclosure experiment was performed, where survival of young larval stages of three anuran species common in the study area, Bufo bufo, 
Pelobates fuscus and Hyla arborea, was investigated in the presence or absence of $1+$ carp. Examining the predatory ability of carp is important because carp is assumed not to be morphologically adapted for sudden attack or pursuit and lacks oral teeth to retain large-bodied resisting prey (Sibbing 1988). Also, carp predation rates on amphibian larvae, which lack hard skeletal parts, can easily be underestimated, due to grinding of soft-bodied prey tissues by carp pharyngeal masticatory apparatus and rapid digestion (cf. Calef 1973; Sibbing 1988). On the other hand, carp benthic activity generates bioturbation, thus modifying the environmental context of carp trophic interactions (Richardson et al. 1995; Haas et al. 2007). Therefore, the experiment was replicated in a $0+$ and a $1+$ pond differing in water turbidity. The $1 \mathrm{~m} \times 1 \mathrm{~m}$ cages, constructed with 1-mm mesh plastic net to allow drift of water and small-sized organisms through the walls, were installed in rows parallel to the shore vegetation in ca. 0.8-m-deep water. The cages were bottomless but closed at the top, bottom edges extending ca. $10-15 \mathrm{~cm}$ into the substrate. The tops of the cages stood ca. $20 \mathrm{~cm}$ above the water line. To create habitat structure, in each cage, three stems of Typha sp. were left or stuck into the bottom and one wall was not fully stretched so that it hung in a U-shape. The species used in the experiments differ in habitat preferences, breeding phenology and individual larval size prior to metamorphosis, with $P$. fuscus larvae attaining the largest body size (Berger 2000). B. bufo is assumed to be unpalatable to fish (Laurila 1998). Tadpoles were collected from multiple clutches from two carp-free ponds and mixed randomly. Each cage received 50 individuals of a single species. Before stocking with the tadpoles, all potential predators were removed from the cages. 'Small-sized' (TL $=12-13 \mathrm{~mm}$ ) B. bufo were added to the cages on 28 April, P. fuscus on 14 May and H. arborea on 29 May, 2008. Additionally, a block of cages with 'largesized' (TL $=60-65 \mathrm{~mm}$ ) P. fuscus tadpoles was established in the $1+$ pond on 29 May. In each block, 1-2 h after tadpoles were introduced, every other cage received one carp of TL $=130-140 \mathrm{~mm}$, i.e., within the size ranges in ponds with $1+$ carp over May-early June (Table S1). Six replicates were used for each treatment, (i.e., 84 cages total in both ponds). Carp and initial tadpole densities were within the approximate ranges of those found in the ponds.

Turbidity levels in cages, measured every 2 weeks using a Hach DR/890 colorimeter between 1 May and 3 June $(0+$ pond, 9-15 FAU; 1+ pond, 20-41 FAU), reflected values typical of $0+$ and $1+$ ponds. Every 1-2 days the fish in enclosures were fed $2-3 \mathrm{~g}$ of granulated food $(35 \%$ protein) per individual. The experiments were terminated after 1 week and the number of surviving tadpoles was determined.
Habitat selection by adult amphibians

To assess the response of breeding amphibians to carp, two measures were used. The entire perimeters of $180+, 151+$ and $102+$ ponds were surveyed from shore between 2006 and 2008 (four surveys per pond, in early April, mid-April, late April-early May, and mid-May) using combined visual encounter surveys and the audio strip transect technique (Heyer et al. 1994). Due to difficulties inherent in estimating the quantitative abundances of adult amphibians (Heyer et al. 1994), especially of large congregations of anurans in $0+$ ponds where chorus sizes were frequently of the order of hundreds of individuals, analysis of data from entire pond perimeter sampling was restricted to species presence/ absence. Additionally, adult individuals were recorded and egg masses were searched for while wading 1-5 $\mathrm{m}$ from the shoreline along two 50-m-long transects haphazardly placed in homogenous habitat on opposite pond margins. A dip-net with a 1.5-m handle was used to capture escaping individuals. In separate analyses on individual taxa, maximal numbers of adult individuals recorded during a single transect visit were used to establish ranked amphibian abundance per $100 \mathrm{~m}$. Ranks used were $0=0$ adult; $1=1-3$ adults; $2=4-10 ; 3=11+$. Analyses were restricted to the six most common "taxa" (each detected in $>30 \%$ of the surveyed ponds): Bombina bombina, P. fuscus, B. bufo, $H$. arborea, water frogs of the Rana esculenta complex, and 'brown frogs' (Rana temporaria and $R$. arvalis were grouped; they consistently oviposited in the same ponds) (see Kloskowski 2009 for a complete list of species). I assumed that pond selection by breeding individuals was not affected by local amphibian densities or pond location, because in each year the ponds studied were densely clustered (separated by only 6- to 12-m-wide levees) and each cluster (pond-complex) contained ponds with different-aged fish. Although recording only females would be a more appropriate measure of breeding habitat preference, for practical reasons all adults were counted, on the assumption that during the oviposition period habitat preferences by males in response to predators correspond to female preferences (Resetarits and Wilbur 1991; Hopey and Petranka 1994). Egg presence/absence was determined in P. fuscus, B. bufo, H. arborea, and 'brown frogs'. In all these taxa, significant positive correlations were found between ranked maximal numbers of adult individuals and egg presence/ absence per $100 \mathrm{~m}$ recorded during one sampling bout (rank-biserial correlation; $n=43$, all $P<0.05$ ). I used densities of adults and presence/absence of egg masses to estimate habitat selection rather than densities of egg masses, because females of some of the study species deposit eggs in multiple clusters or in communal aggregations, or eggs are very difficult to detect (Berger 2000). Also, egg masses may rapidly disappear because of predation 
(Ritke and Mumme 1993); however, monitoring in $1+$ ponds indicated that egg predation was infrequent (J. Kloskowski, unpublished data).

To check whether habitat selection by adult amphibians matched larval densities, two trapping sessions were conducted per each pond using activity traps (the procedure employed was identical to macroinvertebrate and larval amphibian sampling between 2001 and 2004), in the first and second half of June with the sampling interval $>2$ weeks.

\section{Statistical analyses}

Data were compared along the gradient of carp-free, $0+$, $1+$ and $2+$ ponds (hereafter: fish gradient) or only between ponds with different-age carp. Grebe reproductive performance at $2+$ ponds was not estimated, due to too few nesting attempts (see "Results"). When data collection involved repeated sampling across time, or sample sizes were not constant across both random and fixed terms, restricted maximum likelihood (REML) analyses were conducted using GenStat 11.0 (VSN, Hemel Hempstead, UK). Year and pond identity (nested as pond-complex/ pond) were specified as random factors. Critical differences were tested at the 0.05 significance level using the least significant difference (LSD) test. Dichotomous dependent variables (taxa presence/absence) were examined using the generalized linear mixed modelling procedure (GLMM). Pond specific characteristics, including water surface area (ha) and fraction of water surface covered by emergent aquatic vegetation (determined by digitisation from aerial photographs), were included in the analyses as fixed effects. A separate model for grebe fledging success between 2001 and 2004 also included the following as fixed terms: relative total dry weights of macroinvertebrates and relative total wet weights of larval amphibians (both based on activity-trap catches), carp standing biomass (see Table S1 for calculation details), and Secchi depth $(\mathrm{cm})$. The models for abundance of amphibian larvae and invertebrate prey additionally included presence/ absence of breeding grebes, carp standing biomass and Secchi depth. Initial full models contained all variables and their interactions. The non-significant $(P>0.1)$ explanatory terms were then discarded in a backwards stepwise fashion in order of lowest effect size, except where terms were inter-correlated, in which case each individual term was tested independently (in the model with no other fixed effects).

The effects of fish gradient on feeding performance in grebes were analysed by repeated measures mixed models. Weekly pooled provisioning rates per chick per hour expressed as estimated biomass were fitted as the response variable. Brood identity and week after hatching were included as subject and time factor.
Generalised linear models (GLMs) with binomial distribution of errors, logit link function and the dispersion parameter fixed at one were used to inspect the probability of tadpole survival in experimental enclosures/exclosures. The number of surviving tadpoles was fitted as the binomial response variable, with the initial number in each cage as the binomial denominator. In the model for $P$. fuscus, tadpole size category (small-large) was added as a factor. The significance of the explanatory terms was based on the difference in deviance $(\Delta D)$ of models with and without the predictor in question.

When required, variables were either log-, square rootor arcsine square root-transformed. For clarity, data presented in tables and figures were back-transformed.

\section{Results}

Grebe reproductive and feeding performance

Grebe clutch size did not differ along the fish gradient (REML, Wald $\chi^{2}=0.89, d f=2, P=0.643$ ) and did not significantly affect fledgling number (Wald $\chi^{2}=1.65$, $d f=1, P=0.200)$. Overall fledging success depended strongly on the presence and age of fish stocked in ponds $\left(\chi^{2}=141.39, d f=2, P<0.001\right)$. Fledgling production did not significantly differ between carp-free ponds and those stocked with $0+$ fish, but production in both of these pond types was significantly higher than in ponds stocked with $1+$ fish (Fig. 1). Mean fledgling success was 2.8 times higher in $0+$ ponds than in $1+$ ponds ( 2.24 vs 0.80 ; Fig. 1$)$, while mean clutch sizes were comparable (3.95 vs 3.98 , respectively). Forty broods $(37.6 \%)$ in $1+$ ponds failed to fledge any young, whereas total brood failure occurred only once $(0.7 \%)$ in a $0+$ pond. Grebes only occasionally nested on $2+$ ponds (three cases out of 278 nests with hatching success $>0$; only one of these broods fledged chicks). When related to a larger set of environmental variables (data from 2001-2004), fledging success ( $n=63$ broods) was not only affected by the fish gradient $\left(\chi^{2}=16.8\right.$, $d f=2, P<0.001)$, but also positively influenced by larval amphibian abundance $\left(\chi^{2}=6.53, d f=1, \quad P=0.014\right.$; effect $=0.121+$ SE of 0.050$)$. All the other explanatory terms were dropped at $P>0.18$.

In total, 10,958 prey items were observed to be ingested by focal chicks during $963 \mathrm{~h}$ of observations. Estimated biomass consumption per chick increased with brood age $\left(\chi^{2}=28.37, d f=3, P<0.001\right)$. However, consumption was also highly significantly influenced by fish gradient $\left(\chi^{2}=62.90, d f=2, P<0.001\right.$; Fig. 2$)$. The brood age by fish gradient interaction was not significant $\left(\chi^{2}=5.51\right.$, $d f=6, P=0.483)$. Grebes on $0+$ ponds were able to deliver 2.6-3.0 times the prey biomass per chick than pairs 


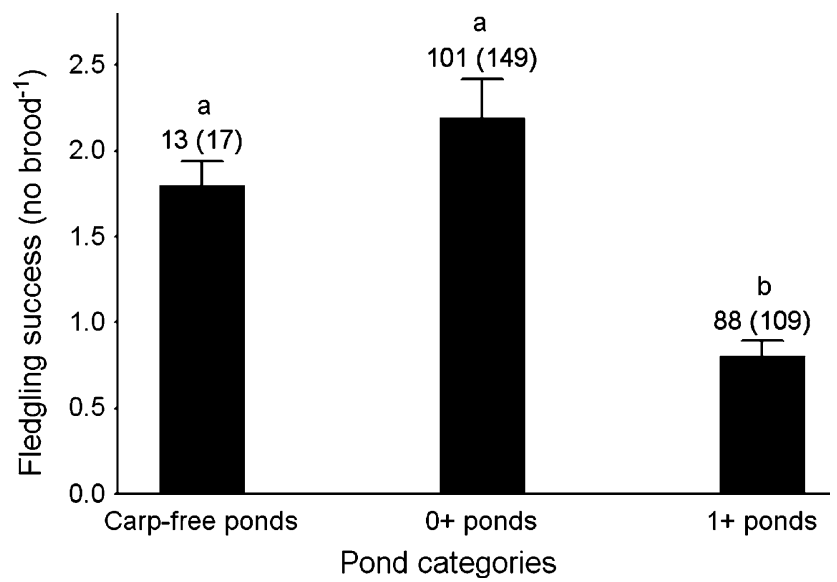

Fig. 1 Fledgling success (mean $+\mathrm{SE}$ ) of red-necked grebes (Podiceps grisegena) breeding on carp-free ponds and ponds with YOY $(0+)$ and over-wintered (1+) common carp (Cyprinus carpio). Fledgling success is the number of fledglings produced per brood in successful nests, where at least one chick hatched. Different letters above bars indicate statistically different means based on LSD test at $P<0.05$. Number of pond/years is shown above each bar with the number of broods in parentheses

on $1+$ ponds (Fig. 2). Given the difference in brood size, parents in $0+$ ponds delivered 3.9-4.4 times the amount of food to chicks in $1+$ ponds.

Grebe and carp diets

On $0+$ ponds, carp was the main prey fed to chicks and the proportion of carp in chicks' diets increased from $48.9 \%$ in the first post-hatching week to $83.3 \%$ in the fourth (Fig. 2). In contrast, over the first 4 weeks after hatching, chicks offered $1+$ carp were never observed to swallow them. Observations focused on parental provisioning of young and most records of feeding by adult involved prey items rejected as too large by young. In 9 of 14 focal families on $1+$ ponds, adult birds were observed to ingest carp until the end of the observation period. Birds on $2+$ ponds were occasionally observed, but adults were never seen to capture $2+$ carp.

Birds territorial on $1+$ ponds (12 of 20 focal pairs) increased their feeding efficiency by making foraging flights to nearby $0+$ ponds; carp was the only prey item delivered to young from neighbouring ponds. The contribution of $0+$ carp to the chicks' diet was low in the first two posthatching weeks $(\leq 5.2 \%)$, but later increased to $>28.0 \%$ (Fig. 2).

Amphibians made up the majority of the biomass of food delivered to broods observed on carp-free ponds and were the second most important prey on $0+$ ponds (Fig. 2). Also, amphibians featured prominently in the food of young grebes on $1+$ ponds (27.4-38.1\%). However, given the total amount of food provided per chick, adults on $0+$
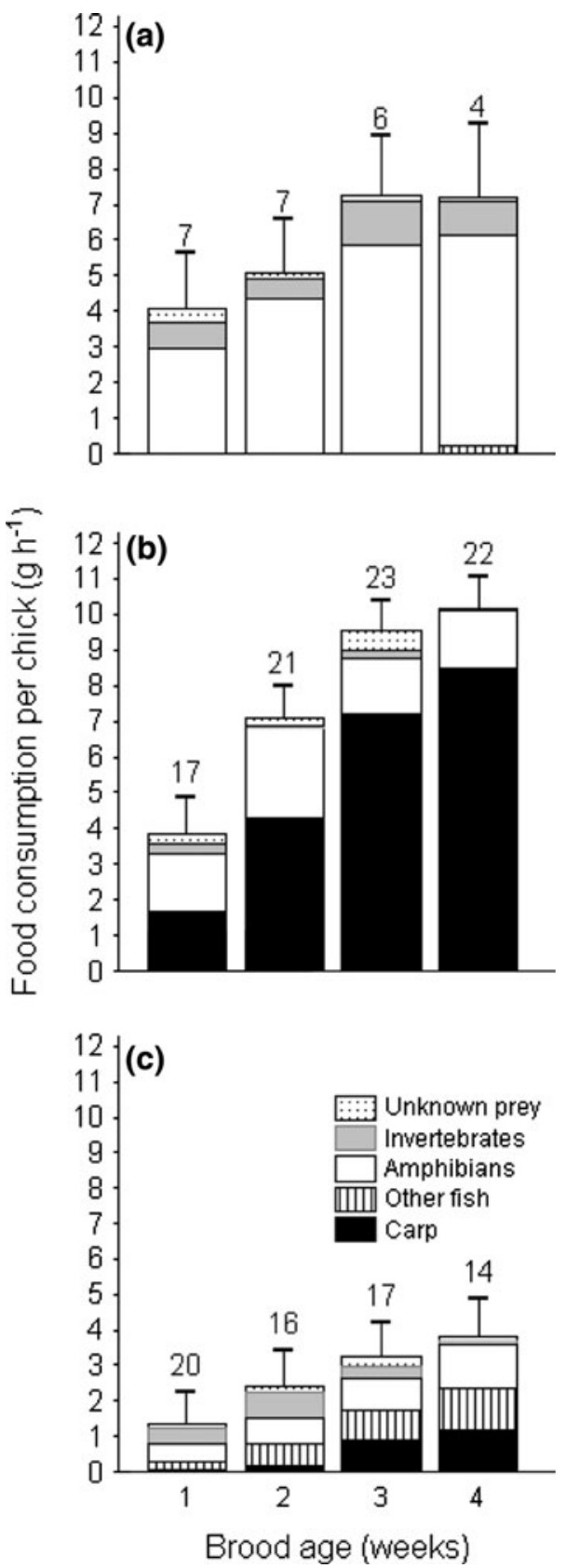

Fig. 2 Food consumption of red-necked grebe chicks during the first 4 weeks of age when reared on a carp-free ponds and ponds with b $0+$ carp and c $1+$ carp (mean $+\mathrm{SE}$, calculated for the overall consumption rate, predicted by a REML repeated-measures model). The number of broods included in the calculations are shown above each error bar. Sample sizes vary over time owing to exclusion of observation sessions with insufficient degree of prey identification (prey items were neither identified nor sized in more than $10 \%$ of feeds) or death of all young before reaching 4 weeks old. All carp in the food of chicks on $1+$ ponds were brought from adjoining $0+$ ponds

ponds delivered on average 2.5 times more amphibian biomass per chick than grebes on $1+$ ponds. Premetamorphic stages predominated ( $>90 \%$ in all broods). On a 
wet weight basis, macroinvertebrates and fish other than carp represented an appreciable portion of chick diets only on $1+$ ponds (Fig. 2). Adult insects formed the bulk (numerically $79.8 \%$ ) of invertebrate prey identified from grebe alimentary tracts.

No remains of vertebrates or adult insects were found in the guts of any carp year class. Microcrustaceans and benthic Diptera consistently predominated (numerically $>87.0 \%$ ) in the alimentary tracts of carp of all sizes (Fig. 3), whereas these prey were absent from grebe diets. Invertebrate taxa present in grebe stomachs were poorly represented in the diet of carp: in $1+$ carp, the age class with the highest level of exploitation of non-dipteran insects, they constituted less than $6.0 \%$ of diet (Fig. 4). Although only invertebrate prey items taken by both carp and grebes were considered (Fig. 4), Schoener's dietary overlap calculated on data pooled over time was low (between grebes and $0+$ carp, SI $=0.03$; with $1+$ carp, $\mathrm{SI}=0.07$; with $2+$ carp, SI $=0.05$ ).

Young grebes could ingest relatively large vertebrate prey. Chicks were fed carp and amphibians with estimated mean lengths of 39-42 mm as early as their first week of life (Fig. S1). Dytiscidae and Odonata prey were also large: $30-40 \mathrm{~mm}$ long. When it was possible to estimate their body length, prey eaten by carp were $<20 \mathrm{~mm}$.

\section{Availability of alternative prey for grebes}

Fish gradient was the only term that significantly affected the total macroinvertebrate biomass in ponds (Table 1). Densities of the taxonomic prey groups most common in

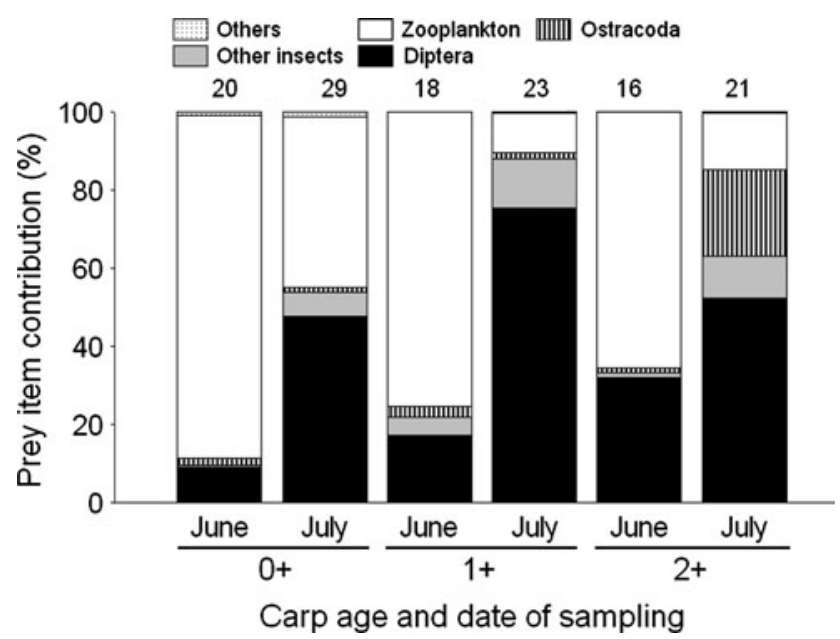

Fig. 3 Relative contribution of different prey items to the animal food of $0+, 1+$ and $2+$ carp in June-July of 2002 and 2004. Other insects were Trichoptera, Coleoptera, Ephemeroptera, Hemiptera, Odonata. Zooplankton includes Cladocera, Copepoda and Rotatoria. The food group Others comprised Nematoda, Oligochaeta and Hydracarina. Carp size ranges (TL): 0+, 20-80 mm; 1+, 110-150 mm, 2+, 210-270 mm. Sample size is shown above each column the traps decreased along the fish gradient. These differences were significant for all taxa but Heteroptera. Densities of amphibian larvae and adult predatory beetles (mainly Dytiscidae) in carp-free and $0+$ ponds did not differ significantly, but surpassed densities in ponds stocked with $\geq 1+$ carp. Total densities of amphibian larvae differed by two orders of magnitude between carp-free ponds and $2+$ ponds (Table 1 ).

\section{Enclosure/exclosure experiment}

Survival rates of caged tadpoles differed depending on the species (palatability) and individual body size (Fig. 5). The survival of $B$. bufo larvae was not affected by the presence of $1+\operatorname{carp}(\Delta D=0.10,1 d f, P=0.748)$ and of the age of fish in the pond where the cages were placed $(\Delta D=1.94$, $1 d f, P=0.164)$. The GLM model including both treatment factors accounted only for $0.9 \%$ of the original deviance. In contrast, presence of $1+$ carp explained $54.61 \%$ of the total deviance in survival of $P$. fuscus $(\Delta D=695.79,1 d f, P<0.001)$ and $96.2 \%$ of $H$. arborea $(\Delta D=1338.15, \quad 1 d f, \quad P<0.001)$, respectively. Carp proved to be a catastrophic agent of mortality in cages (Fig. 5): small-sized tadpoles were eliminated within 2-3 days. Video recordings using a camcorder mounted on cage posts showed that carp preyed on tadpoles by sucking them in like other digestible items of similar size. Large body size increased survival of $P$. fuscus tadpoles enclosed with $1+$ carp: interaction tadpole size*carp presence, $\Delta D=312.07,1 d f, P<0.001$. All other effects were not significant.

Habitat selection by adult amphibians

Amphibian species richness in terms of occurrence of adult individuals or eggs in ponds was significantly affected by the age of carp stocks (REML, Wald $\chi^{2}=159.08, d f=2$, $P<0.001$; predicted means: 6.34 in $0+$ ponds, 2.99 in $1+$ and 1.71 in $2+$ ponds). The taxa detected most frequently in $1+$ and $2+$ ponds were the early breeding $B$. bufo and 'brown frogs' (Fig. 6a). Tadpoles of these species were observed to metamorphose in the first half of June and could be used as food only by the earliest hatching grebe broods. After the earliest breeding species had finished spawning, (i.e., from late April), occurrence of amphibians in $1+$ and $2+$ ponds dropped dramatically; neither mature individuals nor eggs were observed at seven (46.7\%) $1+$ ponds and six $(60 \%) 2+$ ponds (species number: $\chi^{2}=107.51, d f=2, P<0.0001$; predicted means: 4.64 in $0+$ ponds, 1.45 in $1+$ and 0.35 in $2+$ ponds). For all anuran species analysed, ranked numbers of adult individuals per $100 \mathrm{~m}$ of shoreline decreased with the age of stocked carp $\left(\chi^{2} \geq 57.13, d f=2\right.$, all $\left.P<0.01\right)$ except 
Fig. 4 Diet contribution of macroinvertebrate prey as larvae, pupae, and adults based on prey taxa found in the alimentary tracts of a $1+$ carp $(n=41)$ and $\mathbf{b}$ red-necked grebes $(n=18 ; 9$ adults and 9 chicks 1-3 weeks old). Other Coleoptera were small- and medium-sized ( $<30 \mathrm{~mm}$ length) non-predatory taxa

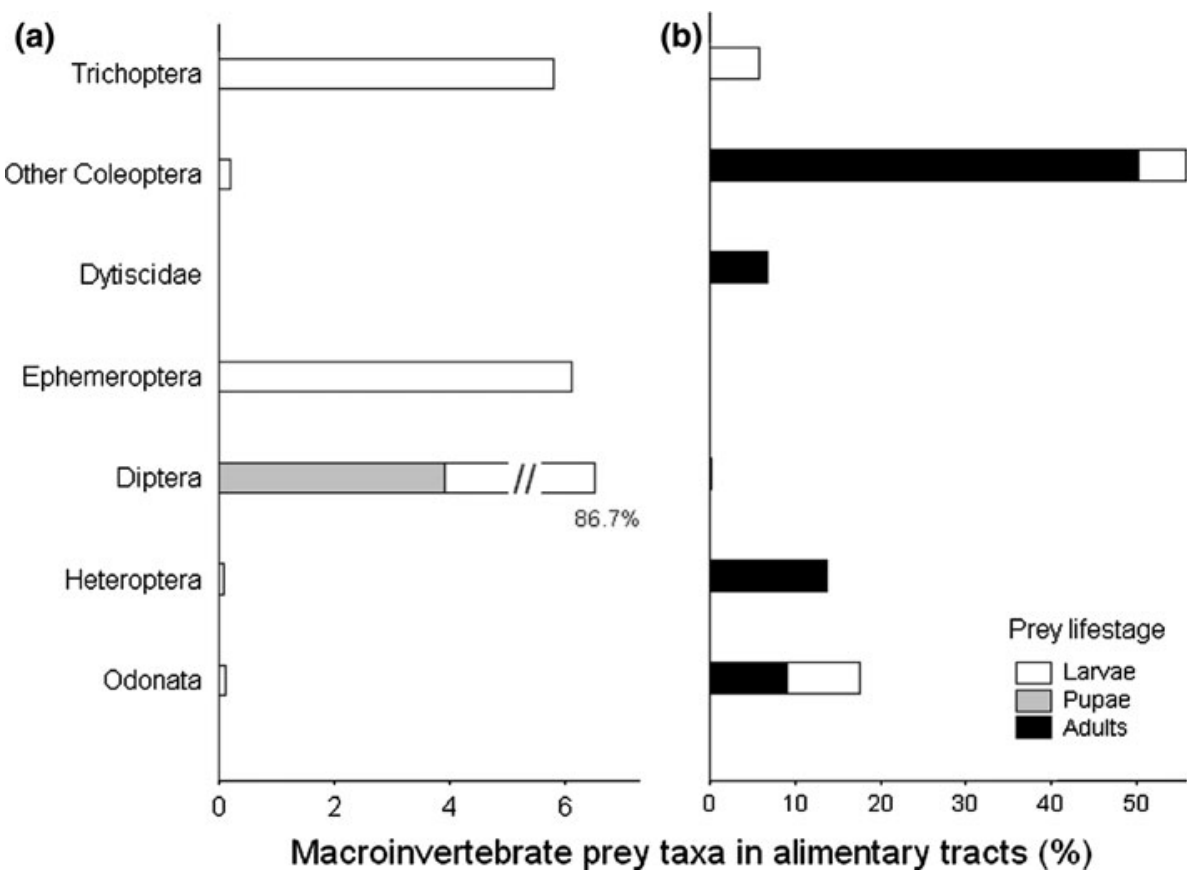

Table 1 Results of REML models comparing mean abundances of non-fish prey of red-necked grebes (Podiceps grisegena) among different pond categories

\begin{tabular}{|c|c|c|c|c|c|c|}
\hline & $\begin{array}{l}\text { Carp-free ponds } \\
(n=2-8)\end{array}$ & $\begin{array}{l}0+\text { ponds } \\
(n=17-28)\end{array}$ & $\begin{array}{l}1+\text { ponds } \\
(n=10-18)\end{array}$ & $\begin{array}{l}2+\text { ponds } \\
(n=7-11)\end{array}$ & SED & $\begin{array}{l}\text { Wald } \chi^{2} \\
(d f=3)\end{array}$ \\
\hline Total macroinvertebrate biomass & $0.865 \mathrm{a}$ & $0.292 \mathrm{~b}$ & $0.044 \mathrm{c}$ & $0.078 \mathrm{c}$ & 0.075 & $51.62 *$ \\
\hline Hirudinea & $0.467 \mathrm{a}$ & $0.136 \mathrm{~b}$ & $0.021 \mathrm{c}$ & $0.044 \mathrm{c}$ & 0.123 & $24.23 *$ \\
\hline Adult predatory beetles & $0.124 \mathrm{a}$ & $0.074 \mathrm{a}$ & $0.002 \mathrm{~b}$ & $0.000 \mathrm{~b}$ & 0.102 & $28.35^{*}$ \\
\hline Heteroptera (adults and nymphs) & $0.051 \mathrm{a}$ & $0.017 \mathrm{a}$ & $0.013 \mathrm{a}$ & $0.012 \mathrm{a}$ & 0.038 & $6.78(\mathrm{NS})$ \\
\hline Odonata larvae & $0.08 \mathrm{a}$ & $0.033 \mathrm{~b}$ & $0.005 \mathrm{c}$ & $0.003 \mathrm{c}$ & 0.049 & $24.73 *$ \\
\hline Amphibian larvae & $127.44 \mathrm{a}$ & $99.32 \mathrm{a}$ & $0.941 \mathrm{~b}$ & $0.016 \mathrm{~b}$ & 1.744 & $84.55^{*}$ \\
\hline
\end{tabular}

Larval amphibians and macroinvertebrates were sampled using activity traps in 2001, 2002 and 2004 (see the main text for more details). The age of carp was the only predictive factor in all models. All other terms tested (pond surface area, emergent pond vegetation, carp standing biomass, Secchi depth, presence/absence of breeding grebes) were excluded from models with $P>0.1$. Invertebrate biomasses were expressed in terms of dry weight, amphibian biomasses in terms of wet weight (g per 10 activity traps per pond). $P$ values were Bonferroni corrected. Backtransformed means of square root-transformed data are shown. Values with the same letter are not significantly different by LSD test at $P<0.05$ $n$ numbers of ponds sampled each year, in 2001, 2002 and 2004, SED average standard error of the differences for carp year classes (SEDs are not back-transformed), NS no significant difference

$* P<0.01$

B. bufo $\left(\chi^{2}=5.48, d f=2, P=0.077\right.$; Fig. 6a). The same patterns were found for presence/absence of egg batches (GLMM, Wald $\chi^{2}=36.00, d f=2$, all $P<0.0001$, except B. bufo, $\chi^{2}=2.02, d f=2, P=0.373$ ). In all amphibian taxa, relative larval densities (maximal numbers of larvae trapped on one sampling occasion) in ponds were positively related to densities of adult individuals (REML, Wald $\chi^{2} \geq 4.64, d f=1$, all $P \leq 0.03$ ). Apart from $B$. bufo $\left(\chi^{2}=2.59, d f=2, P=0.285\right)$, larval densities of all species were also affected by carp age $\left(\chi^{2} \geq 22.97, d f=2\right.$, all $P<0.001$ Fig. 6b; as densities of adult amphibians and carp age were correlated, these effects were tested in separate models to limit the effects of multicollinearity).

\section{Discussion}

Food availability and reproductive success of grebes along fish size gradient

Changes in prey fish size-structure strongly affected the reproductive success of grebes. With growth, stocked carp 

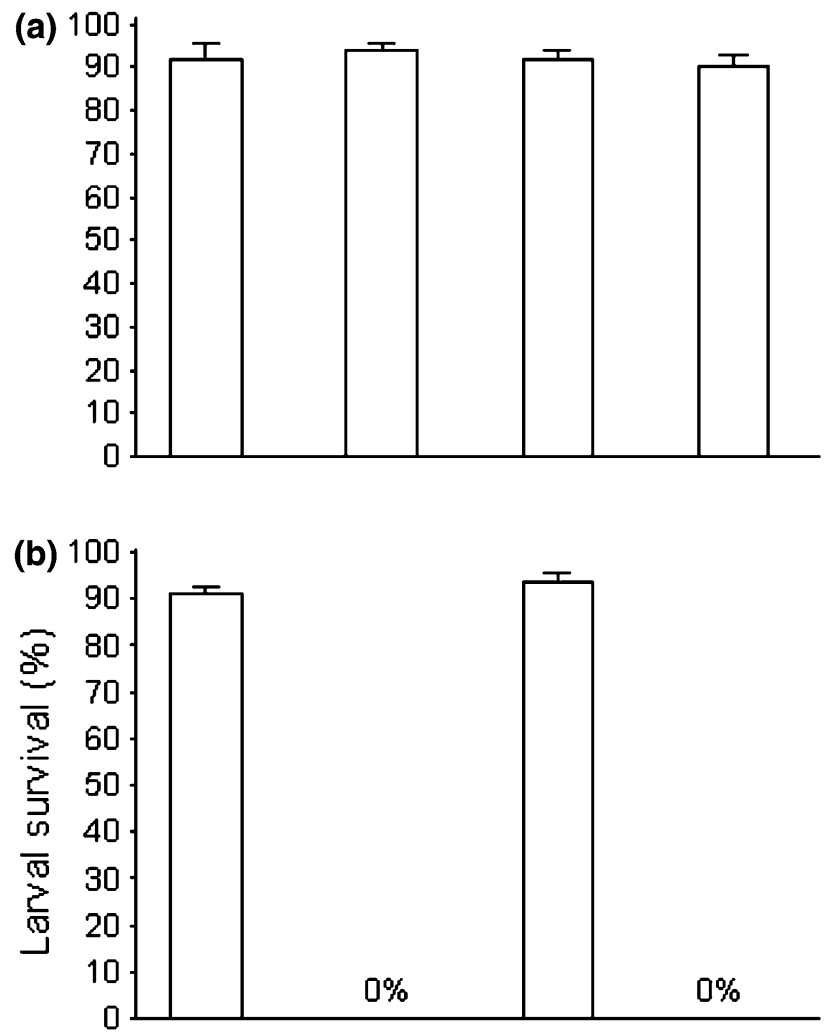

(c)

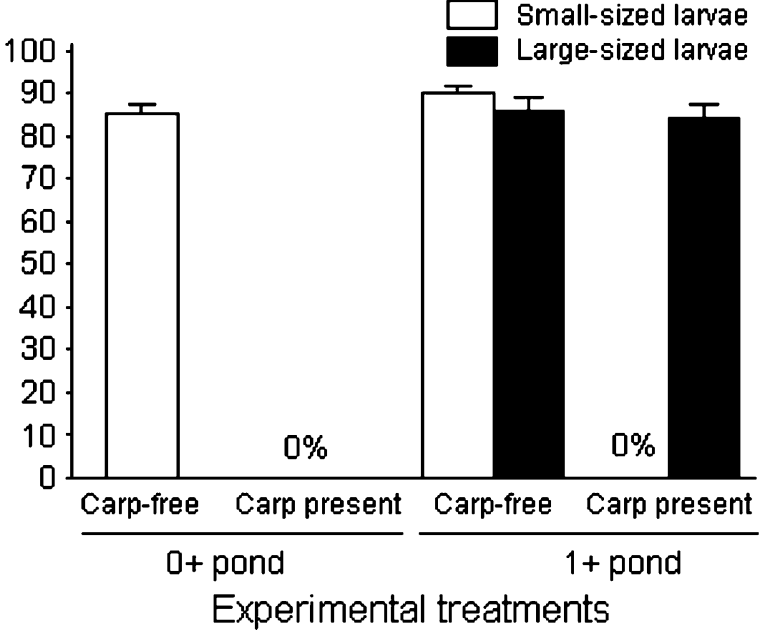

Fig. 5 Survival of a Bufo bufo, b Hyla arborea and c Pelobates fuscus larvae in the absence (carp-free) and presence (carp present) of $1+$ carp in exclosures/enclosures placed in ponds with $0+$ and $1+$ carp for 1 week (mean $+\mathrm{SE}$ ). At stocking, small-sized larvae ranged in size from 12 to $13 \mathrm{~mm}$ TL. Only P. fuscus larvae were enclosed at large size (60-65 mm TL) and only in the $1+$ pond (see text for details)

were capable of attaining a size refuge from grebe predation. While $0+$ fish made up an essential part of the food of young grebes, $2+$ fish could not be ingested even by adult birds. $1+$ carp were too large to be eaten by chicks, but still contributed to the diet of adults. A few carp of a size close
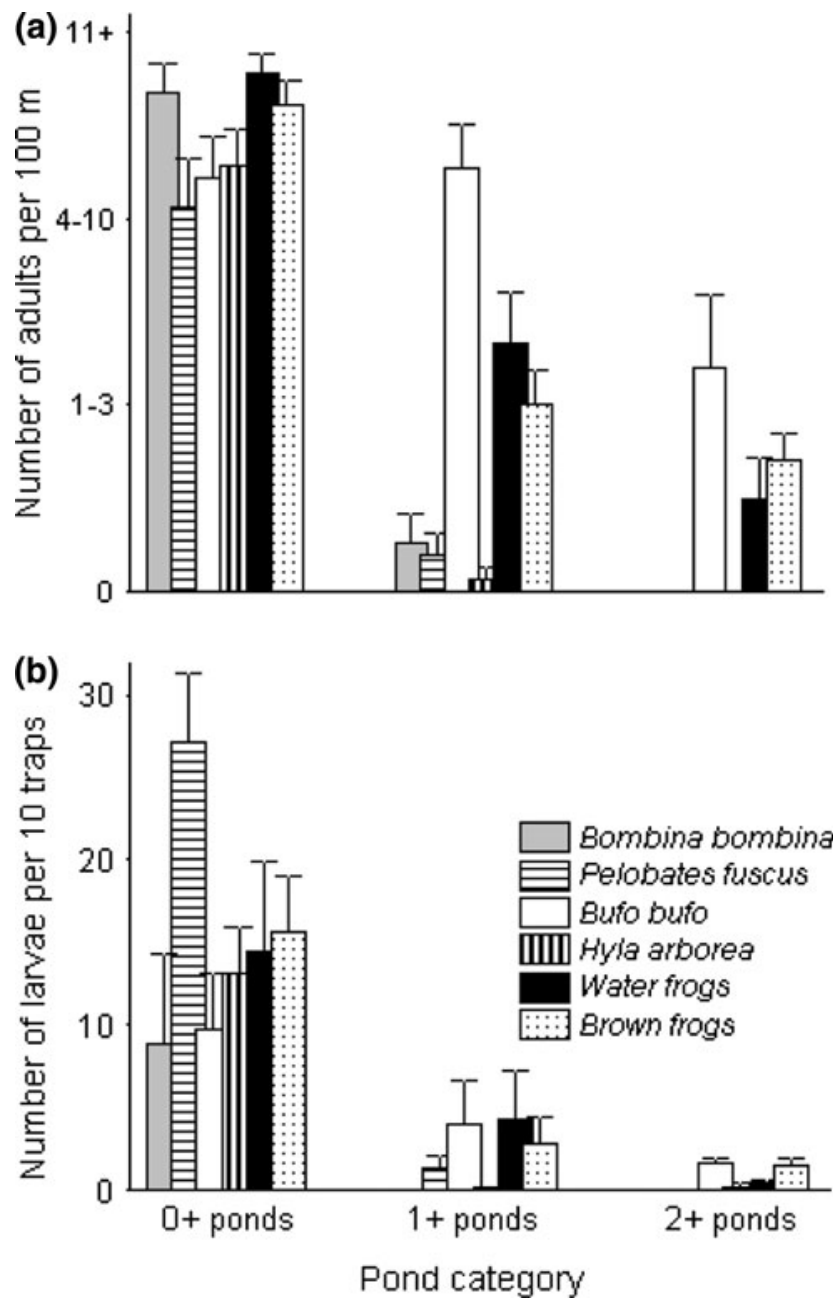

Fig. 6 a Estimated abundance of adult anurans (Bombina bombina, Pelobates fuscus, Bufo bufo, Hyla arborea, 'water frogs' and 'brown frogs') ranked in 4 categories: 0 adult, $1-3$ adults, $4-10$ adults, $\geq 11$ adults (mean number per $100 \mathrm{~m}$ of shoreline + SE) in ponds with $0+$, $1+$, and $2+$ carp. b Relative abundance of larval anurans (mean number per 10 activity traps per $24 \mathrm{~h}+\mathrm{SE}$ ) in ponds with $0+, 1+$, and $2+$ carp

to the upper limit of vulnerability to adult grebes are sufficient to meet their daily food demand (assumed to be ca. 150-180 g; Piersma 1988). Moreover, adult birds could fly to adjoining ponds to feed. However, food availability of grebe broods clearly paralleled the fish gradient. Chicks in $1+$ ponds received 2.6-3-fold less prey biomass than chicks in $0+$ ponds. Consequently, nearly $38 \%$ of broods in $1+$ ponds produced no fledglings. On average, pairs on $1+$ ponds raised less than one young to independence, a fledgling success ca. 2-3-fold lower than in other parts of Europe (reviewed in Vlug 2002). The lack of association between clutch size and fledging success, low feeding rates at $1+$ ponds and patterns of post-hatching mortality (Kloskowski 2003) suggest that reproductive performance in grebes was primarily regulated by food availability for 
chicks. Pairs on $1+$ ponds lessened their dependence on resources available locally on nesting ponds by searching for food in $0+$ ponds, but this provisioning strategy was rarely employed in the earliest post-hatching period which is critical for chick survival. Foraging flights may have incurred serious energetic costs with relatively low delivery rates (Ohanjanian 1989; Jackson 2003). Grebes clearly avoided $2+$ ponds, i.e., the habitat with the lowest food availability, thus presumably escaping heavy brood losses.

Due to a high energetic return, fish are a profitable prey for birds (Jackson 2003; McParland and Paszkowski 2006). When fish at a size ingestible for chicks proved to be in short supply in $1+$ ponds, $0+$ carp was the only prey item brought in by parents after foraging flights. However, low fish availability alone is unlikely to affect grebes, which are opportunist predators able to use fish and non-fish prey as equivalent resources and to breed successfully on fishless waters (Fjeldså 2004; McParland and Paszkowski 2006; this study). Besides the fish gradient, larval amphibian abundance was the only factor to significantly affect grebe fledging success. No significant effect of macroinvertebrate abundance was found, but pooled invertebrate abundance may not be a good indicator of macroinvertebrate availability for grebes, as certain taxa or developmental stages may be of special importance. Also, unless suppressed by carp, amphibian prey was more important for grebes in terms of weight than macroinvertebrates. Non-fish prey may be easier for adults to capture or (when small-sized or soft-bodied) for hatchlings to ingest (Fjeldså 1982; Piersma 1988). In the critical earliest brood period, even birds territorial on $0+$ ponds relied heavily on amphibians and macroinvertebrates. Even if $0+$ carp negatively affected non-fish resources of grebes (but no significant effect on amphibians was found as compared with carp-free ponds), $0+$ carp served as prey and contributed substantially to grebe reproductive success. However, the decline of nonfish prey coupled with the attainment by carp of a size refuge from young grebes appears decisive in creating a food shortage for grebe chicks in ponds stocked with larger carp.

Large-sized carp effects on grebes' resources

The mechanisms behind the impact of large carp on nonfish prey resources of grebes are potentially a mix of diverse interactions. Carp is a size-limited predator, therefore its capacity to gather resources shared with grebes might increase with body size. Food competition between carp and grebes was apparently unimportant, but amphibian larvae, as soft-bodied prey, are likely to be underestimated in the alimentary tracts of fish (Calef 1973). In cage experiments, effects driven by carp predation overshadowed other potential pathways of suppression of amphibian larvae, such as competition or habitat degradation. Larval stages of the amphibian species studied rely mainly on algae which are of no dietary importance for carp (reviewed in Sibbing 1988). Also, tadpoles kept on starvation diets may survive for many weeks (Calef 1973). Bioturbation associated with carp bottom-feeding habits may affect invertebrates and amphibians (Scheffer 1998; deMaynadier and Hunter 1995). However, amphibian larvae kept in carp exclosures had similar survival rates in ponds differing in turbidity levels. Survival of unpalatable $B$. bufo tadpoles was unaffected by carp, but this supports the key role of predation in extirpation of the other anuran species. Still, cage experiments might demonstrate carp's potential to prey on amphibian larvae rather than reflect natural mortality rates in ponds, because of the smaller spatial scale and limited refugia within cages (Cooper et al. 1990). Both gut content examination and cage experiments indicated that $1+$ carp were able to exploit only the lower end of prey sizes taken by chicks. The macroinvertebrate diet of carp was composed exclusively of larvae and pupae, whereas grebes ate adult insects. Such prey size (life stage) specialisation is considered to be a factor allowing for niche partitioning or even mutual facilitation by predators (Schoener 1974; De Roos et al. 2008). On the other hand, carp might significantly suppress the recruitment of the grebe's alternative prey to larger sizes (subsequent stages), which would be more energetically profitable or easier for birds to capture, via predation on early developmental stages that lack active escape behaviour or occur on the pond bottom (cf. Osenberg et al. 1994; Olson et al. 1995). However, diets of grebes and carp displayed little overlap in taxonomic composition.

Non-trophic effects provide another class of explanations for the impact of large carp on non-fish resources of grebes. As larval stages of most temperate pond-breeding amphibians and macroinvertebrates lack specific defences against fish predators, fitness of breeding individuals in the form of offspring survivorship may largely depend on proper oviposition site choice (Resetarits and Wilbur 1991; Resetarits 2001). In fact, all amphibian species except the inedible $B$. bufo tended to avoid ponds with large fish. In more than half of $1+$ and $2+$ ponds, neither adults nor eggs were detected for anurans other than B. bufo and early breeding 'brown frogs'. Adult amphibians have a substantial escape capacity and are typically too large to be vulnerable to attack by carp. Thus, their low densities at ponds with larger carp cannot be ascribed to direct predation. Identifying causal links between habitat selection by breeding amphibians, patterns of larval abundance in ponds, and food availability for grebes would require a rigorous experimental design. Such experiments are particularly difficult when many species interact simultaneously 
(Abrams 1992). However, the strong response of breeding amphibians to the discrete distribution of carp age-cohorts suggests that avoidance behaviour by adult stages may explain decreases in the abundance of larvae better than direct consumption by fish alone. Similar avoidance-based mechanisms may explain the distribution patterns of some aquatic insects, as indicated by low densities of highly mobile imago forms of predatory beetles in the $1+$ and $2+$ ponds compared to carp-free and $0+$ ponds. Strong nontrophic effects of large-sized fish on amphibians or macroinvertebrates may be common in a wide range of bird-fish systems and indirectly affect birds (see also LeBourdais et al. 2009). Even when they lack the ability to take relatively large prey, large-bodied intermediate consumers like fish are more likely to function as "keystone intimidators" (sensu Peckarsky et al. 2008) of the lower trophic levels than avian top predators. They are usually more proficient at using particular (e.g. early developmental) stages of the resources, and more numerous than top predators. Actual predatory pressure may be difficult to identify behind such a pattern of interactions, because non-trophic effects can occur independently of consumptive rates (Werner and Peacor 2003). In the present study, the ability of large carp to deplete the alternative prey of its predator was confirmed by a manipulative closed-system experiment, whereas field observations in an open system (where adult amphibians were free to select breeding habitats) suggest little natural predatory interaction.

Negative effects of fish on waterbirds have typically been attributed to unstructured interactions, mainly competition (e.g. Eriksson 1979; Eadie and Keast 1982; Wagner and Hansson 1998). As fish communities are often distinctly structured (Werner and Gilliam 1984; Persson et al. 1991), incorporation of size structure into explanatory models may help to elucidate fish effects on spatial distribution and reproductive success of many waterbirds. In studies suggesting competition between fish and piscivorous birds (Eriksson 1986; van Eerden et al. 1993; Wagner and Hansson 1998), it would be worthwhile to consider rather a size-dependent mixture of competitive and predatory interactions. Many non-piscivorous taxa, such as ducks or rallids, are likely to be affected by fish size structure as well, because they rely in large part on a protein-rich invertebrate diet in the prefledging period (cf. Eadie and Keast 1982; LeBourdais et al. 2009) and the intensity of fish impact on these resources may vary with individual fish size. Birds are able to migrate to alternate habitat patches, at least between subsequent reproductive bouts, so the strength of interactions with fish depends on proper patch choice by breeding individuals and on the relative availability of favourable versus hostile, (i.e. dominated by large-bodied fish) habitats. Shifts in size structure of fish populations due to natural processes or external perturbations (Persson et al. 1991; Paszkowski and Tonn 2000; De Roos and Persson 2002) may substantially alter the suitability of aquatic habitats for waterbirds over time. In the present study, the dominant fish at small size had a positive trophic effect on the reproductive success of the avian predator, at medium size exerted a negative impact on food availability for broods and at large size excluded the birds from the habitat. Furthermore, the present results indicate that in systems where a fish as a dominant intermediate consumer is able to attain a size refuge from an avian predator, its indirect adverse influence on the predator may not be confined to trophic mechanisms. These observations may apply to a wider range of prey-predator interactions, wherever the non-trophic effects of an intermediate consumer on lower trophic levels can loop back, indirectly affecting the recruitment of the top predator.

Acknowledgments Thanks to J. Kot, J. Krogulec, M. Nieoczym, M. Polak, K. Styła and P. Szewczyk for field assistance, and G. Kahlan and W. Płaska for the diet analyses. I am indebted to the fish farmers (M. Filipiak, J. Orzepowski and M. Sagan) for their cooperation. I am grateful to J. Vlug and two anonymous referees for their constructive criticisms and to J. Jones and M. Urban for improving the English of earlier versions of the manuscript. Financial support was provided by grants from the State Committee for Scientific Research (KBN 6 PO4F06620 and 3 PO4F03623) and from the Polish Ministry of Science and Higher Education (MNiSW 2 P04G05030).

Open Access This article is distributed under the terms of the Creative Commons Attribution Noncommercial License which permits any noncommercial use, distribution, and reproduction in any medium, provided the original author(s) and source are credited.

\section{References}

Abrams PA (1992) Predators that benefit prey and prey that harm predators: unusual effects of interacting foraging adaptations. Am Nat 140:573-600

Abrams PA, Menge BA, Mittelbach GG, Spiller D, Yodzis P (1996) The role of indirect effects in food webs. In: Polis GA, Winemiller KO (eds) Food webs: integration of patterns and dynamics. Chapman and Hall, New York, pp 371-395

Berger L (2000) Amphibians and reptiles of Poland. PWN, Warszawa-Poznań

Binckley CA, Resetarits WJ Jr (2002) Reproductive decisions under threat of predation: squirrel treefrog (Hyla squirella) responses to banded sunfish (Enneacanthus obesus). Oecologia 130:157161

Byström P, Persson L, Wahlström E (1998) Competing predators and prey: juvenile bottlenecks in whole-lake experiments. Ecology 79:2153-2167

Calef GW (1973) Natural mortality of tadpoles in a population of Rana aurora. Ecology 54:741-758

Cooper SD, Walde SJ, Peckarsky BL (1990) Prey exchange rates and the impact of predators on prey populations in streams. Ecology $71: 1503-1514$ 
Crivelli AJ (1981) The biology of the common carp, Cyprinus carpio L. in the Camargue, southern France. J Fish Biol 18:271290

de Maynadier PG, Hunter ML (1995) The relationship between forest management and amphibian ecology: a review of the North American literature. Environ Rev 3:230-261

De Roos AM, Persson L (2002) Size-dependent life-history traits promote catastrophic collapses of top predators. Proc Natl Acad Sci USA 99:12907-12912

De Roos AM, Schellekens T, van Kooten T, Persson L (2008) Stagespecific predator species help each other to persist while competing for a single prey. Proc Natl Acad Sci USA 105: 13930-13935

Diamond J (1986) Overview: laboratory experiments, field experiments, and natural experiments. In: Diamond J, Case TJ (eds) Community ecology. Harper and Row, New York, pp 3-21

Eadie JM, Keast A (1982) Do Goldeneye and perch compete for food? Oecologia 55:225-230

Eriksson MOG (1979) Competition between freshwater fish and Goldeneyes Bucephala clangula (L.) for common prey. Oecologia 41:99-107

Eriksson MOG (1986) Reproduction of Black-throated Diver Gavia arctica in relation to fish density in oligotrophic lakes in southwestern Sweden. Ornis Scand 17:245-248

Fjeldså J (1982) The adaptive significance of local variations in the bill and jaw anatomy of North European red-necked grebes Podiceps grisegena. Ornis Fenn 59:84-98

Fjeldså J (2004) The Grebes-Podicipedidae. Oxford University Press, Oxford

Griffiths RA (1985) A simple funnel trap for studying newt populations and an evaluation in smooth and palmate newts, Triturus vulgaris and Triturus helveticus. Br J Herpetol 1:5-10

Haas K et al (2007) Influence of fish on habitat choice of water birds: a whole-system experiment. Ecology 88:2915-2925

Heyer WR, Donnelly MA, McDiarmid RW, Hayek LC, Foster MS (1994) Measuring and monitoring biological diversity. Standard methods for amphibians. Smithsonian Institution Press, Washington

Hopey ME, Petranka JW (1994) Restriction of wood frogs to fish-free habitats: how important is adult choice. Copeia 1994:1023-1025

Jackson DB (2003) Between-lake differences in the diet and provisioning behaviour of black-throated divers Gavia arctica breeding in Scotland. Ibis 145:30-44

Kloskowski J (2001) Temporal patterns of parental resource distribution in the red-necked grebe: equalizing the share of the survivors. Behaviour 138:1355-1370

Kloskowski J (2003) Brood reduction in the red-necked grebe Podiceps grisegena. Ibis 145:233-243

Kloskowski J (2004) Food provisioning in Red-necked Grebes (Podiceps grisegena) at common carp (Cyprinus carpio) ponds. Hydrobiologia 525:131-138

Kloskowski J (2009) Size-structured effects of common carp on reproduction of pond-breeding amphibians. Hydrobiologia 635: 205-213

Kloskowski J, Grela P, Krogulec J, Gąska M, Tchórzewski M (2006) Sexing Red-necked Grebes Podiceps grisegena by molecular techniques and morphology. Acta Ornithol 41:176-180

Laurila A (1998) Breeding habitat selection and larval performance of two anurans in fresh water rock-pools. Ecography 21:484-494

LeBourdais SV, Ydenberg RC, Esler D (2009) Fish and harlequin ducks compete on breeding streams. Can J Zool 87:31-40

Lima SL, Dill LM (1990) Behavioral decisions made under the risk of predation: a review and prospectus. Can J Zool 68:619-640

Madsen FJ (1957) On the food habits of some fish eating birds in Denmark. Dan Rev Game Biol 3:19-83
McParland CE, Paszkowski CA (2006) Effects of small-bodied fish on invertebrate prey and foraging patterns of waterbirds in Aspen Parkland wetlands. Hydrobiologia 567:43-55

Moser ME (1986) Prey profitability for adult grey herons Ardea cinerea and the constraints on prey size when feeding young nestlings. Ibis 128:392-405

Murkin HR, Abbott PG, Kadlec JA (1983) A comparison of activity traps and sweep nets for sampling nektonic invertebrates in wetlands. Freshw Invertebr Biol 2:99-106

Neill WE (1975) Experimental studies of microcrustacean competition, community composition and efficiency of resource utilization. Ecology 56:809-826

Ohanjanian IA (1989) Food flights of red-necked grebes during the breeding season. J Field Ornithol 60:143-153

Olson MH, Mittelbach GG, Osenberg CW (1995) Competition between predator and prey-resource-based mechanisms and implications for stage-structured dynamics. Ecology 76:17581771

Osenberg CW, Olson MH, Mittelbach GG (1994) Stage structure in fishes: resource productivity and competition gradients. In: Stouder DJ, Fresh KL, Feller RJ (eds) Theory and application in studies of fish feeding ecology. University of South Carolina Press, Columbia, pp 151-170

Paszkowski CA, Tonn WM (2000) Community concordance between the fish and aquatic birds of lakes in northern Alberta, Canada: the relative importance of environmental and biotic factors. Freshw Biol 43:421-437

Peckarsky BL et al (2008) Revisiting the classics: considering nonconsumptive effects in textbook examples of predator-prey interactions. Ecology 89:2416-2425

Persson L, Diehl S, Johansson L, Andersson G (1991) Shifts in fish communities along the productivity gradient of temperate lakes: patterns and the importance of size-structured interactions. J Fish Biol 38:281-294

Piersma T (1988) Body size, nutrient reserves and diet of red-necked and slavonian grebes, Podiceps grisegena and P. auritus on Lake IJsselmeer. Bird Study 34:13-24

Resetarits WJ Jr (2001) Colonization under threat of predation: avoidance of fish by an aquatic bettle, Tropisternus lateralis (Coleoptera: Hydrophilidae). Oecologia 129:155-160

Resetarits WJ Jr, Wilbur HM (1991) Calling site choice by Hyla chrysoscelis-effect of predators, competitors, and oviposition sites. Ecology 72:778-786

Richardson MJ, Whoriskey FG, Roy LH (1995) Turbidity generation and biological impacts of an exotic fish Carassius auratus, introduced into shallow seasonally anoxic ponds. J Fish Biol 47:576-585

Ritke ME, Mumme RL (1993) Choice of calling sites and oviposition sites by gray treefrogs (Hyla chrysoscelis)-a comment. Ecology 74:623-626

Scheffer M (1998) Ecology of shallow lakes. Chapman and Hall, London

Schoener TW (1970) Non synchronous spatial overlap of lizards in patchy habitats. Ecology 51:408-418

Schoener TW (1974) Resource partitioning in ecological communities. Science 185:27-39

Sibbing FA (1988) Specialization and limitations in the utilization of food resources by the carp, Cyprinus carpio: a study on oral food processing. Environ Biol Fish 22:161-178

Ulenaers P, van Vessem J, Dhondt AA (1992) Foraging of the great crested grebe in relation to food supply. J Anim Ecol 61:659-667

Urban MC (2007) Predator size and phenology shape prey survival in temporary ponds. Oecologia 154:571-580

Van Eerden MR, Piersma T, Lindeboom R (1993) Competitive food exploitation of Smelt Osmerus eperlanus by great crested grebes 
Podiceps cristatus and perch Perca fluviatilis at Lake IJsselmeer, The Netherlands. Oecologia 93:463-474

Vlug JJ (2002) Red-necked grebe. BWP Update 4:139-179

Wagner BMA, Hansson L-A (1998) Food competition and niche separation between fish and the red-necked grebe Podiceps grisegena (Boddaert, 1783). Hydrobiologia 368:75-81

Wallace RK (1981) An assessment of diet-overlap indexes. Trans Am Fish Soc 110:72-76
Werner EE, Gilliam JF (1984) The ontogenetic niche and species interactions in size-structured populations. Annu Rev Ecol Syst 15:393-425

Werner EE, Hall DJ (1979) Foraging efficiency and habitat switching in competing sunfishes. Ecology 60:256-264

Werner EE, Peacor SD (2003) A review of trait-mediated indirect interactions in ecological communities. Ecology 84:1083-1100 